\title{
COMPARATIVE STUDY OF THE APPLICATION OF JASMONIC ACID AND PESTICIDE IN CHILLI: EFFECTS ON PHYSIOLOGICAL ACTIVITIES, YIELD AND VIRUSES CONTROL.
}

\author{
ESTUDO COMPARATIVO DA APLICAÇÃO DE ÁCIDO JASMÔNICO E PESTICIDA \\ EM PIMENTEIRA: EFEITO NAS ATIVIDADES FISIOLÓGICAS, PRODUÇÃO E \\ CONTROLE DE VIROSES
}

\author{
Noor Asma’a AWANG'; ${ }^{1}$ Mohd Razi ISMAIL ${ }^{1}$; Dzolkhifli OMAR ${ }^{2}$; M. Robiul ISLAM ${ }^{1,3}$ \\ 1. Laboratory of Food Crops, Institute of Tropical Agriculture, Universiti Putra Malaysia, Serdang 43400, Selangor, Malaysia; \\ 2. Department of Plant Protection, Universiti Putra Malaysia, Serdang 43400, Selangor, Malaysia; 3. Department of Agronomy and \\ Agricultural Extension, Rajshahi University, Rajshahi 6205, Bangladesh. razi@ putra.upm.edu.my
}

\begin{abstract}
The excessive application of pesticides for agricultural production has raised quite some concern about environmental safety and sustainability. To reduce environmental impact of pesticide overuse, there is an increasing interest in using different elicitors including Jasmonic acid (JA) to induce resistance against pathogen and insect in crop. Chilli (Capsicum annuum L.), which is an important vegeTable cum spice crop around the world. The aims of this study were to compare the effectiveness of Jasmonic acid on growth, Phyto-physiological responses, yield and viruses control in chilli plant. It was evaluated the effectiveness of single spray of JA (JA1), double spray of JA (JA2), conventional pesticide (Malathion 50\%) and without any of those or control. The experimental results showed that pesticide-treated plants perform much better at early growth stages and become less competitive to JA2 treatment at maturity. Double spray of jasmonic acid showed less stress symptoms in different antioxidant enzymes activities (GPX, APX and CAT), reduce percentage of disease incidence and severity as well as improve growth and yielding characters of chilli plant. Therefore application of Jasmonic acid in chilli could be a possible alternative of pesticide application and its two times exogenous spray $(0.5 \mathrm{mM})$ is most effective.
\end{abstract}

KEYWORDS: Induced resistance. Oxidative stability. Alternative control of plant disease. Disease severity.

\section{INTRODUCTION}

The chilli (Capsicum annuum L.) belongs to the family Solanaceae is one of the most important vegeTable as well as spice crops around the world, valued for its aroma, taste, flavor and pungency. Besides traditional uses, it is also being used in pharmaceuticals, cosmetics and beverages (TIWARY et al., 2005). In Malaysia, total chilli production reached about 32.8 thousand tons per year in 2010 with about 2.8 thousand hectares of areas under cultivation (DOA, 2011). Meanwhile, the total consumption of the country reached up to 50 thousand tons per year. Due to insufficient national production the country need to expend a considerable amount of currency to import chilli either in the form of fresh, dried or powdered. However, the average chilli productivity in Malaysia is very low compared to that in other neighboring countries. To achieve desirable production of chilli, it is important to increase production as well as cultivation area. Management of different disease and pests are also important factor for better crop production. Chilli is infested by more than 21 insects and non-insect pests and leaf curl disease and chilli veinal mottle virus
(CVMV) are most common in Malaysia (SHIH et al., 2006; AROGUNDADE et al., 2012), and some herbivores insect such as aphid, thrips and mites are considered as the most devastating pests are also act as a vector for the transport of plant viruses (THALER et al., 1996).

The farmers always give priority to protecting such a high value crop and to mitigate the negative consequences of pest outbreaks and improve profits. Sometime farmers used huge amount of pesticides indiscriminately to protect the crop without proper diagnosis which results in resurgence of the pests, phytotoxicity on fruits, infertility and presence of high amount of pesticidal residue on harvested fruits.

Extensive use of pesticides has now become a threat to natural agro-ecosystem as well as human health (DAVID, 1991; AWASTHI et al., 2001). Taking into consideration concerns about the sustainability of input-intensive agriculture and the economic, ecologic, and environmental effects of pesticides over-use, it is clear that over all application of pesticide should be reduced and agricultural scientists and planners are now looking for the possible alternatives of the agrochemicals and pesticides. 
Several studies have proved that exogenous application of Jasmonic acid (JA) enhanced resistance to herbivore challenge and induce the expression of defense related genes (LORENZO and SOLANO, 2005; HOWE and JANDER, 2008). Moreover, JA are also involved with different physiological activities such as seed germination, tuber formation, tendril coiling, leaf senescence, stomata opening, fruit ripening and root growth, and also play crucial roles in plant defense responses against insect damage and microbial pathogens attack (WASTERNACK, 2007).

Although there is limited understanding of disease-resistance mechanisms, physiological and molecular biological studies have documented several plant responses to disease resistance. This work was developed to compare the effectiveness of Jasmonic acid on growth, Phyto-physiological responses, yield and viruses control in chilli plant, using eco-physiological features.

\section{MATERIAL AND METHODS}

\section{Plant material and cultivation}

Mature and healthy seeds of hot chilli F1 hybrid (Capsicum annuum L.) were germinated in the seed tray containing peat moss and kept under protected area to enhance germination and prevent direct sunlight. Uniform seedlings were transplanted into polybag containing coconut coir dust and empty fruit bunch compost with ratio $(3: 1 \mathrm{v} / \mathrm{v})$ as media substrate. Plants were transplanted individually and randomly inside a greenhouse. Plants were watered as required and fertilized with Modified Cooper Formulation two times per day during the experiment. Plants were maintained in the greenhouse under natural sunlight with $60-80 \%$ relative humidity while photosynthetically active radiation was $500-700 \mu \mathrm{molm}^{-2} \mathrm{~s}^{-1}$.
AWANG, N. A. et al.

\section{Treatment applications:}

Jasmonic acid (Sigma - Aldrich) was stored at $5^{\circ} \mathrm{C}$ until needed. To prepare the spray solution, JA was dissolved in acetone at rate $1 \mathrm{~g} / \mathrm{ml}$ and made up to a concentration of $0.5 \mathrm{mM}$ with distilled water and $0.1 \%$ of Tween-20 was added as surfactant. Control treatments consisted of distilled water with same acetonolic solutions and $0.1 \%$ Tween-20 minus JA (Cooper and Rieske, 2011). First application of the above solution was made first week after transplanted (5-6 leaf stage), whereas hot pepper plants in each plot was sprayed until run off using a hand sprayer. Second applications were done on third week after transplanted (9-11 leaves stage) according to their treatments approximately. About $10 \mathrm{ml}$ of JA solution was applied per plant on average. The treatments were $0.5 \mathrm{mM}$ JA $1 \mathrm{x}$ spray, $0.5 \mathrm{mM}$ JA $2 \mathrm{x}$ spray, Pesticide spray and water (Untreated). Three replicates of each treatment were organized in a randomized completely block design (RCBD). Malathion (0.5\%), the most common pesticide for chilli, was used for this experiment.

\section{Disease severity}

Due to higher disease infection rates in the experimental region and plants were grown in an open greenhouse, no pathogen was inoculated artificially. Common viral infection symptoms such as, chlorotic, necrotic, curling, mottling, stunting or bunching symptom were considered for assessment of disease severity.. Plant was measured by eye estimation starting one week after treatments were applied. Disease symptoms that were appeared on plant was rated by using a modified grading scheme index (Table 1) from Galanihe et al., (2004), hence calculated according to the formula below for disease severity index (DSI):

$$
\left.\operatorname{DSI}(\%)=\sum\{(\mathrm{P} \times \mathrm{Q})\} /(\mathrm{M} \times \mathrm{N})\right] \times 100
$$

where, $\mathrm{P}=$ severity score, $\mathrm{Q}=$ number of infected plants having same score, $\mathrm{M}=$ total number of plants observed, and $\mathrm{N}=$ maximum rating scale number (4).

Table 1. Disease rating scales used in scoring observed diseases on chilli plants in the field.

\begin{tabular}{c|l}
\hline Scale & \multicolumn{1}{c}{ Symptom of damage } \\
\hline 0 & No disease symptom (0\%). \\
\hline 1 & $1-25 \%$ of the canopy showing disease symptoms. \\
\hline 2 & $25-50 \%$ of the canopy showing disease symptoms. \\
\hline 3 & $50-75 \%$ of the canopy showing disease symptoms. \\
\hline 4 & $>75 \%$ of the canopy showing disease symptoms. \\
\hline
\end{tabular}




\section{Disease incidence:}

The plants were monitored weekly after treatments were applied by recording the expression of disease or damage symptoms to assess disease incidence. The proportion of infected plants per plot was calculated and expressed as a percentage of disease incidence (GALANIHE et al., 2004).

\section{Plant morphology:}

Four randomly tagged plants were selected to measure stem and canopy diameter. Stem and canopy diameter was determined at mid-vegetative stage (27 DAT), flowering or fruit setting stage (40 DAT), early fruiting stage (60DAT) and maturation stage (80DAT).

\section{Biomass partitioning}

After harvest (120 DAT), three randomly selected plants from each treatments were selected to determine biomass partitioning in leaves, stem (include branches) and roots. The roots were gently washed under running water to remove all adhering media. Then, dry weight of each plant parts were measured using an electric balance (QC 35EDE-S Sartorius, Germany) and root-shoot ratio was calculated as root dry weight divided by total leaf and stem dry weight.

\section{Yield parameters}

Chilies were ready to harvest while the color of fruits changed from green to intermediate reddish. Mature chilies were harvested at 5 days interval up to end of experiment on 120 days after transplanting (120 DAT). Weight, length and diameter of randomly sampled 4 chilies from each harvest were measured for fruit characteristics.

\section{Relative chlorophyll content and chlorophyll fluorescence}

Relative chlorophyll content was measured on the upper most fully expanded leaves of the four individual plants per treatment at vegetative, flowering or fruit setting, fruiting and maturation stages using chlorophyll meter (SPAD 502, MINOLTA $^{\text {TM }}$ Camera Ltd. Japan. The measurement of fast chlorophyll fluorescence was taken on the upper surface of the latest fully expanded leaves from four individual plants per treatments at 09:00 to 10:00 hours, which was used for primary photochemistry detection. Prior to fluorescence measurements, a circular surface of the upper face was dark-adapted for 30 minute using dark clips, hence the induction curve (Fv/Fm ratio) was then estimated by a Plant Efficiency Analyzer (Handy PEA, Hansatech Ltd King's Lynn, Norfolk,
England) with $600 \mathrm{Wm}^{-2}$ of red (630) light intensity (excitation intensity). $\mathrm{Fv} / \mathrm{Fm}$ provides an estimation of the maximum photochemical efficiency or quantum yield of photosystem II (PSII) was analyzed to evaluate alteration by treatment (OUZOUNIDOU et al., 2010).

\section{Leaf photosynthetic rate}

An open-path porTable photosynthesis system (Li-6400XT, LI-COR, Lincoln, NebraskaUSA) was used to determine the net photosynthetic rate $\left(\mu \mathrm{mol} \mathrm{m} \mathrm{m}^{-2} \mathrm{~s}^{-1}\right)$ per unit leaf area. Three uppermost young fully expanded leaves of the five individual plants per treatments were randomly chosen and measured at midday (10 to $11 \mathrm{AM}$ ). The data were taken at vegetative, flowering or fruit setting, fruiting and maturation stages.

\section{Determination of enzymatic activities}

To examine the enzymatic activity, samples of leaf tissue were taken at different growth stages (vegetative, flowering, fruiting and maturation). The leaves were removed with scissors and immediately frozen in liquid nitrogen and stored in a refrigerator at $-80^{\circ} \mathrm{C} .0 .5 \mathrm{~g}$ of frozen leaf tissue was weighed and immediately ground with a pestle in mortar using liquid nitrogen. Samples were homogenized in $5 \mathrm{ml}$ of $50 \mathrm{mM}$ potassium phosphate buffer $(\mathrm{pH} 7.0)$, containing $0.1 \mathrm{mM}$ ethylenediaminetetraacetic acid (EDTA), 4\% (w/v) polyvinylpyrrolidone and 0.2 $\mathrm{mM}$ ascorbic acid. The homogenate was then centrifuged at $10000 \mathrm{rpm}$ for 10 minutes. The supernatant were stored at $-80^{\circ} \mathrm{C}$ until analysis for enzyme determination studies (EL-KHALLAL, 2007). Guaicol peroxidase activity (GPX) was measured using method modified from Nakano and Asada (1981). 1ml of reaction mixture consisting solution of $71.4 \mathrm{mM}$ potassium buffer $(\mathrm{pH} 7.0)$, $1 \mathrm{mM}$ EDTA (prepared with potassium buffer), $1 \mathrm{mM}$ hydrogen peroxide and $100 \mu \mathrm{l}$ of $100 \mathrm{mM}$ guaicol as electron donor. About a minute after equilibration, the reaction was started by adding $100 \mu 1$ of the extract and the activities were determined by measuring the increase in absorbance during 30 seconds at $420 \mathrm{~nm}$ in a spectrophotometer (extinction coefficient $26.6 \mathrm{mM}^{-1} \mathrm{~cm}^{-1}$ ). GPX activity was expressed as change in absorbance $\mu$ molmin $^{-}$ ${ }^{1} \mathrm{mg}^{-1}$ of protein. Ascorbate peroxidase activity (APX) was measured using method modified from Rao et al., (1996). Twenty $\mathrm{ml}$ of the extract from each sample was added into $2 \mathrm{ml}$ of assay mixture, containing of solution of $400 \mu \mathrm{l}$ of $100 \mathrm{mM}$ potassium buffer $\mathrm{pH} 7.5,200 \mu \mathrm{l}$ of $1 \mathrm{M}$ ascorbic acid, $400 \mu \mathrm{l}$ of $0.2 \mathrm{mM} \mathrm{H}_{2} \mathrm{O}_{2}$ and $0.98 \mathrm{ml}$ distilled water. The mixture was mixed thoroughly and the increase 
in absorbance of $\mathrm{H}_{2} \mathrm{O}_{2}$ was monitored at 290nm for 3 minutes (extinction coefficient $2.8 \mathrm{mM}^{-1} \mathrm{~cm}^{-1}$ ) using spectrophotometer. Ascorbate peroxidase activity (APX) was expressed as change in absorbance $\mu$ molmin ${ }^{-1} \mathrm{mg}^{-1}$ protein. Catalase activity (CAT) was measurement with modified from Aebi and Bergmeyer (1983). 120 $\mu$ l of the enzyme extract was added to reaction mixture consisted $2.8 \mathrm{ml}$ of $50 \mathrm{mM}$ phosphate buffer $(\mathrm{pH}=7.0)$ and $80 \mu \mathrm{l}$ of $\mathrm{H}_{2} \mathrm{O}_{2}$. Catalase activity was determined by measuring the increase in absorbance of $\mathrm{H}_{2} \mathrm{O}_{2}$ during $1 \mathrm{~min}$ at $240 \mathrm{~nm}$ in a spectrophotometer with $3 \mathrm{ml}$ of total reaction mixture. CAT activity was expressed as change in absorbance by mmolmin $\mathrm{mg}^{-1}$ protein.

\section{Statistical analysis}

An analysis of variance was performed using the SAS software (SAS, 2009). Duncan
Multiple Range Test (DMRT) at $\mathrm{P} \leq 0.05$ was used to test differences between the treatments.

\section{RESULTS AND DISCUSSION}

\section{Disease severity and disease incidence}

Virus infection severity (DS) indices were higher in jasmonic acid treated plants at early growth stages (Vegetative and flowering) compared to pesticide treatment and almost similar at fruiting stage. (Figure 1, A). However, at maturation stage DS was found significantly 28.69 and $67.59 \%$ lower for JA1 and JA2 treatment compared with pesticide application. The most severe disease and pest attacks were favored on untreated plants at all growth stages.
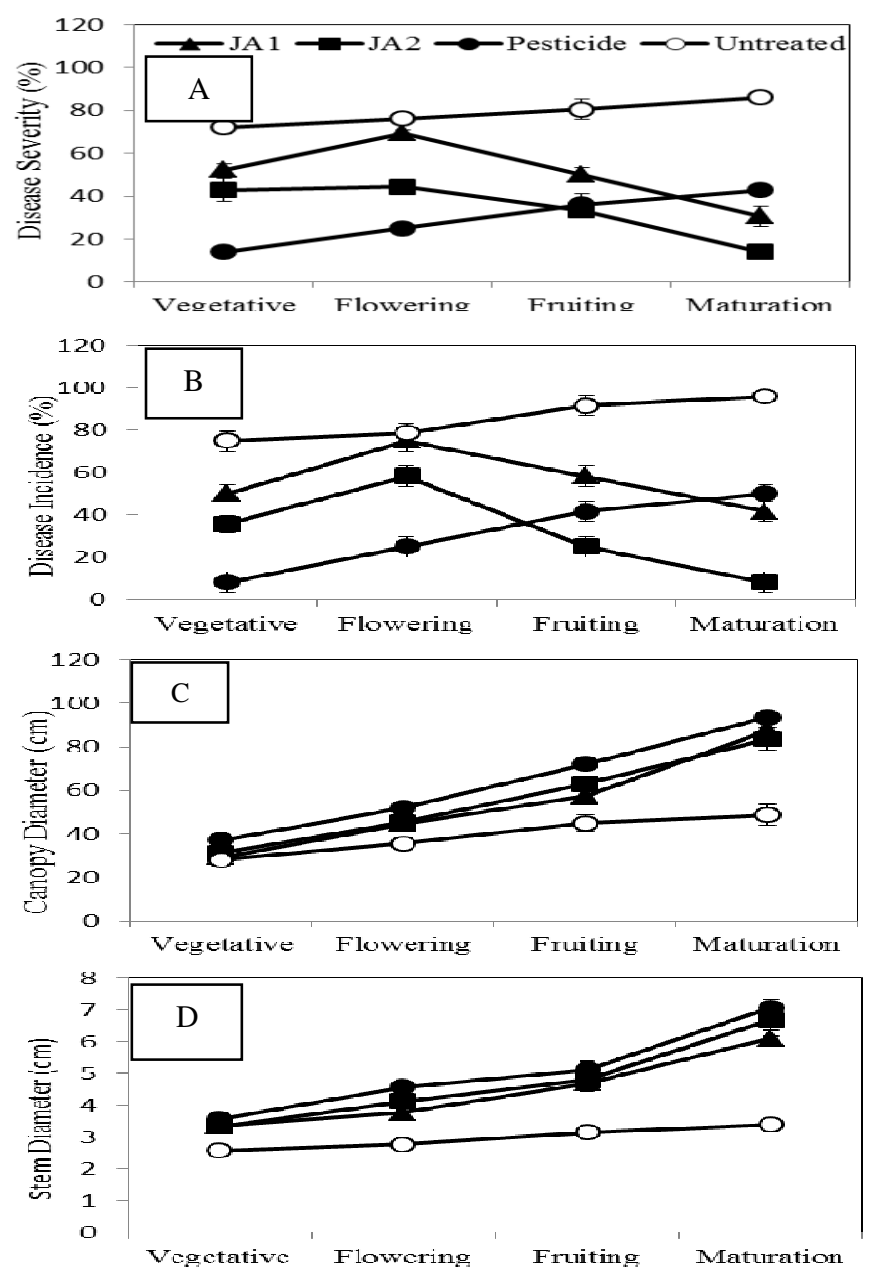

Figure 1. Effect of jasmonic acid and pesticide on (A) viral disease severity (B) disease incidence (\%), canopy diameter (C) and stem diameter (D) in chili plants. Vertical bars indicate standard errors.

The major diseases in chilli plant caused due to viruses which transmitted through thrips. During early growth stages (Vegetative and flowering) Jasmonic acid treated plants showed higher disease incidence rate but gradually reduced in the maturity stage (Figure 1, B). Although there was no significant different observed between the treatments JA1 and pesticide application, disease 
incidence rate at maturity was significantly $(83.4 \%)$ lower in JA2 treatment compared with pesticide application. The highest disease incidence rate was found in control or untreated chilli plants in all growth stages.

\section{Canopy diameter and stem diameter}

Both jasmonic acid treatments and pesticide application results significantly increase $(P \leq 0.05)$ in canopy diameter than the untreated plants, while the difference between jasmonic acid treatments and pesticide application varied marginally during maturity (Figure 1, C). Mean stem diameter of chili plants treated with jasmonic acid was significantly greater than untreated plants but lower than pesticide treatment. A marked increase of $29.1 \%$, $48.6 \%, 52.4$ and $96.5 \%$ in stem diameter was noted for plant with JA2 treatment at vegetative, flowering, fruiting and maturity stage respectively

\section{Relative chlorophyll content and chlorophyll fluorescence}

Relative chlorophyll content in chilli plants under different treatments are presented in Figure 2, $A$ and no significant difference was noted at vegetative stage. However, relative chlorophyll content was significantly higher in both jasmonic acid and pesticide treated plants at flowering stage. At fruiting stage, JA2 treatment was significantly higher than other treatments and control plants. At the maturation stage, JA2 was not significantly different with pesticides-treated plants, but significantly higher $(p \leq 0.01)$ of relative chlorophyll content compared to the JA1 (one time JA sprayed) and untreated plants. The maximum quantum yield of primary photochemistry ( $\mathrm{Fv} / \mathrm{Fm}$ ratio) showed no significant differences among the treatments except control at vegetative stage (Figure 2, B).

(Figure 1, D).
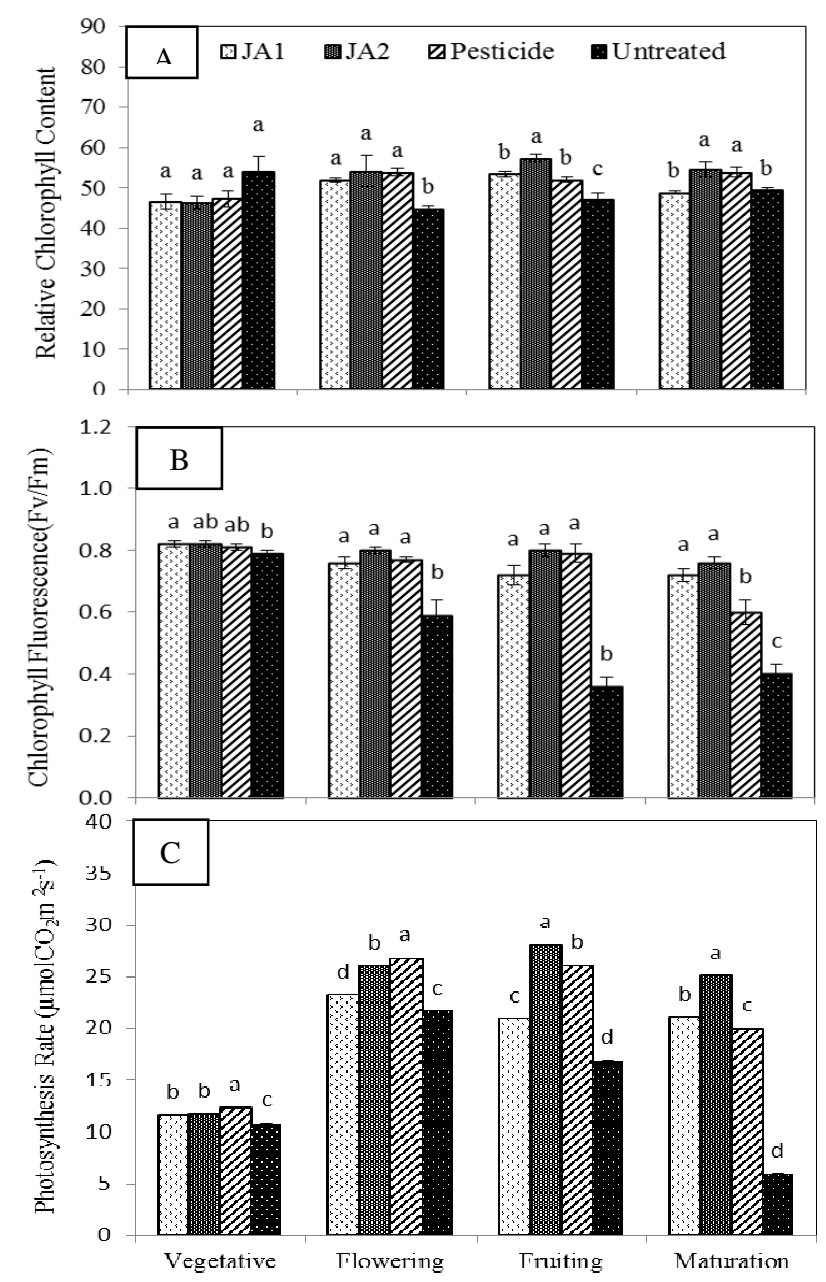

Figure 2. Effect of jasmonic acid and pesticide on the relative chlorophyll content (A), chlorophyll fluorescence (B) and Photosynthesis rate (C) in chili plants at different growth stages. Vertical bars indicate standard errors. Means followed by the same letter are not differ significantly. JA1 = Jasmonic acid 1x spray; JA2 = Jasmonic acid 2x spray; Pesticide spray and Untreated control. 
The chlorophyll fluorescence was significantly depressed in untreated or control plant compared with the both jasmonic acid and pesticidetreatment at flowering and fruiting stage. At maturation, the increase of $\mathrm{Fv} / \mathrm{Fm}$ ratio was significantly higher under both jasmonic acid treatments than in untreated and pesticide-treated plant while the lowest value of $\mathrm{Fv} / \mathrm{Fm}$ ratio was recorded in untreated plants.

\section{Photosynthesis rate}

Pesticide treated plants dominate in Photosynthesis rate at early growth stages (vegetative and flowering) and become less competitive at maturity. At vegetative and flowering stages, JA2 treatment showed a significant $(\mathrm{P} \leq 0.001)$ acceleration by $8 \%$ and $20.4 \%$ than untreated or control plants (Figure 2, C). However, photosynthesis rate progressively increased at the fruiting stage resulted in gradual recovery from
AWANG, N. A. et al.

disease incidence. The photosynthesis rate of plants treated with exogenous applied JA2 was significantly higher than that in untreated and pesticide-treated plants, while the lowest value were presented under untreated plants at fruiting and maturation stage.

\section{Biomass partitioning and yield}

Leaf, stem, root and total dry matter determination of chili plants revealed that jasmonic acid application especially two times spray (JA2) had remarkable effect to increase dry matter content compared with untreated plants. Although single spray of jasmonic acid (JA1) perform lower than pesticide treatment, JA2 treatment increased leaf dry weight, stem dry weight, root dry weight and total dry weight by $208.6,365.3,360.0$ and $300.4 \%$ respectively compared to control (Table 2). Root: shoot ratio of chilli plants treated with JA2 was also significantly greater than untreated plants.

Table 2. Mean dry matter production and partitioning $\left(\mathrm{g}_{\text {plant }}{ }^{-1}\right)$ of chilli plant as affected by the exogenous jasmonic acid and pesticide application at 120 days after transplanting.

\begin{tabular}{llllll}
\hline Treatment & $\begin{array}{l}\text { Leaf Dry } \\
\text { Weight } \\
\text { (g/plant) }\end{array}$ & $\begin{array}{l}\text { Stem Dry } \\
\text { Weight } \\
\text { (g/plant) }\end{array}$ & $\begin{array}{l}\text { Root Dry } \\
\text { Weight } \\
\text { (g/plant) }\end{array}$ & $\begin{array}{l}\text { Root: } \\
\text { Shoot } \\
\text { Ratio }\end{array}$ & $\begin{array}{l}\text { Total Dry } \\
\text { Weight } \\
\text { (g/plant) }\end{array}$ \\
\hline JA1 & $92.19 \mathrm{~b}$ & $151.71 \mathrm{~b}$ & $34.38 \mathrm{~b}$ & $0.14 \mathrm{~b}$ & $278.28 \mathrm{~b}$ \\
$\mathrm{JA2}$ & $144.73 \mathrm{a}$ & $264.85 \mathrm{a}$ & $46.97 \mathrm{a}$ & $0.12 \mathrm{c}$ & $456.56 \mathrm{a}$ \\
Malathion (0.5\%), & $101.06 \mathrm{~b}$ & $156.72 \mathrm{~b}$ & $45.58 \mathrm{a}$ & $0.18 \mathrm{a}$ & $303.36 \mathrm{~b}$ \\
Untreated & $46.89 \mathrm{c}$ & $56.92 \mathrm{c}$ & $10.21 \mathrm{c}$ & $0.09 \mathrm{~d}$ & $114.03 \mathrm{c}$
\end{tabular}

Means followed by the same letters within a column are not significantly different at $\mathrm{P} \leq 0.05$ by the Least Significant Difference (LSD) test.

A remarkable increase in total yield, fruit number, fruit weight and fruit length of chili was obtained with JA2 treatments, followed by pesticides-treated plants and JA1, while untreated plants presented the lowest yield and fruit number per plant (Table 3). This total yield was found $573.4 \%$ higher for JA2 treatment than untreated or control plants. Jasmonic acid two times spray (JA2) produces the longest fruits by $45.6 \%$ and $24.7 \%$ higher from untreated and pesticide-treated plants. Pesticide-treated plants presented widest diameter followed by JA2 and JA1, while untreated plants produces lowest fruit diameter (Table 3). Although single spray of jasmonic acid (JA1) also increased yield and yield components significantly compared to control, it was slightly less than pesticide performance.

\section{Antioxidant enzymes activities}

Antioxidant enzymes activities under different treatments are presented in Figure 3 and it was observed that Jasmonic acid application had remarkable effect on studied parameters. The enzymatic activities of GPX, APX and CAT were higher at early growth stages and gradually decreased with time and most of the cases control or untreated plants showed the higher values of those enzyme activities whereas JA2 showed the lowest (Figure 3). 
Table 3: Mean total yield, fruit number and fruit characteristics of chilli as affected by the exogenous jasmonic acid and pesticide application at 120 days after transplanting.

\begin{tabular}{llllll}
\hline Treatments & $\begin{array}{l}\text { Yield } \\
\left(\mathrm{g} \text { plant }{ }^{-1}\right)\end{array}$ & $\begin{array}{l}\text { Number of } \\
\text { fruit / plant }\end{array}$ & $\begin{array}{l}\text { Fruit Weight } \\
(\mathrm{g})\end{array}$ & $\begin{array}{l}\text { Fruit } \\
\text { Length } \\
(\mathrm{cm})\end{array}$ & $\begin{array}{l}\text { Fruit } \\
\text { Diameter } \\
(\mathrm{cm})\end{array}$ \\
\hline & & & & & \\
JA1 & $1387.64 \mathrm{c}$ & $108 \mathrm{~b}$ & $12.87 \mathrm{c}$ & $14.05 \mathrm{c}$ & $5.33 \mathrm{~b}$ \\
$\mathrm{JA} 2$ & $1965.73 \mathrm{a}$ & $132 \mathrm{a}$ & $16.38 \mathrm{a}$ & $19.58 \mathrm{a}$ & $5.08 \mathrm{~b}$ \\
& & & & & \\
Malathion $(0.5 \%)$, & $1493.20 \mathrm{~b}$ & $116 \mathrm{~b}$ & $14.57 \mathrm{~b}$ & $15.70 \mathrm{~b}$ & $5.93 \mathrm{a}$ \\
Untreated & $291.90 \mathrm{~d}$ & $37 \mathrm{c}$ & $9.88 \mathrm{~d}$ & $13.45 \mathrm{c}$ & $4.40 \mathrm{c}$
\end{tabular}

Means followed by the same letters within a column are not significantly different at $\mathrm{P} \leq 0.05$ by the Least Significant Difference (LSD) test.
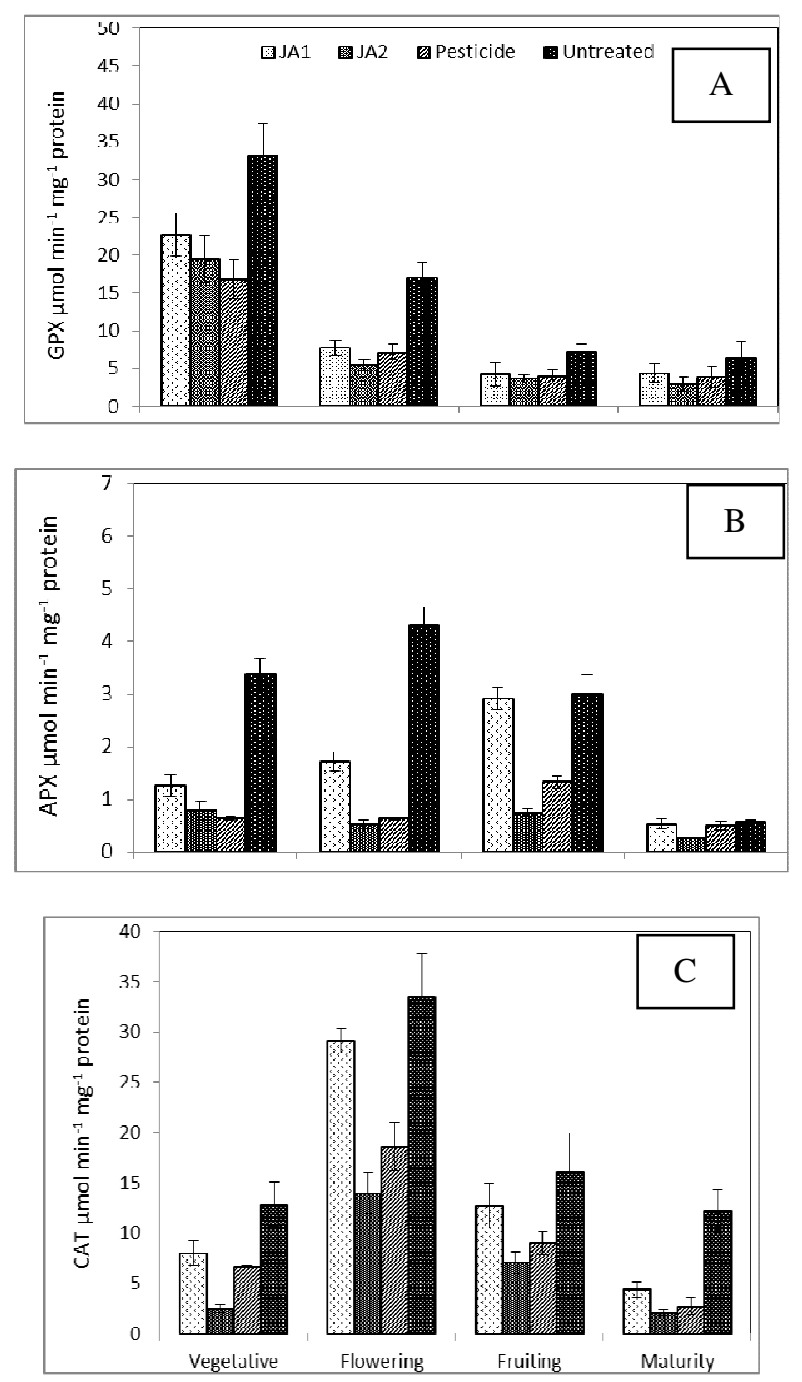

Figure 3: Effect of jasmonic acid and pesticide on GPX, APX and CAT activities in chili leaves at different growth stages. Vertical bars indicate standard errors; JA1 = Jasmonic acid 1x spray; JA2 = Jasmonic acid 2x spray; Pesticide spray and Untreated control. 
The GPX activity was significantly high in untreated or control plants at all growth stages whereas difference between the other treatments are negligible although JA2 showed the lowest values (Figure 3, A). APX activity was highest at flowering stage and gradually decreased over time (Figure 3, B). The APX activity was remarkable high in control plants at all growth stages except maturity. CAT activity was also found height at flowering stage (Figure 3,C) and the value was significantly higher at all growth stages in control plants and lowest with JA2 .

In the present experiment, as expected, treatment with $0.5 \mathrm{mM}$ JA two times sprayed (JA2) was shown to be an effective elicitor due to reduce antioxidant enzyme activities in leaves of chili plants and ultimately reduce percentage of disease incidence and severity as well as improve growth and yielding characters in chilli plants. Some previous studies have also examined the effects of jasmonic acid shown in induce resistance against various insects in soybean (CREELMAN et al., 1992), tomato (THALER, 1999), celery (BLACK et al., 2003), tobacco (von DAHL; BALDWIN, 2004), wheat (JAYARAJ et al., 2004), cotton (BARBOSA et al., 2008) and potato (IL'INSKAYA1 et al., 2000).

During our experiment Exogenous JA reduced the disease incidence and severity indices compared to untreated plants. However, pesticidetreated plants showed significantly higher performance at early growth stages and become less competitive to JA2 treatment over time. Similar finding was also reported by Cipollini and Redman (1999) as the application of JA induce resistance in plant to defense herbivores attack and diseases for a long time.

Pesticide may reduce fruit quantity as well as environmental contamination, whereas no negative effect on environment was reported for Jasmonic acid application (THALER, 1999). Therefore application of Jasmonic acid in chilli could be a possible alternative of pesticide application and its two time spray $(0.5 \mathrm{mM})$ is most effective.

\section{CONCLUSIONS}

Effectiveness of jasmonic acid for physiological adjustments, growth, yield and disease incidence was studied and it was observed that that pesticide-treated plants showed a rapid growth at early growth stages and become less competitive to JA2 treatment at maturity.

Two time exogenous application of jasmonic acid $(0.5 \mathrm{mM})$ showed less stress symptoms in different antioxidant enzymes activities (GPX, APX and CAT), reduce percentage of disease incidence and severity as well as improve growth and yielding characters of chilli plant.

The application of Jasmonic acid in chilli could be a possible alternative of pesticide application and its two time spray $(0.5 \mathrm{mM})$ is most effective.

RESUMO: A aplicação excessive de pesticidas na produção agrícola tem provocado algumas alterações na segurança ambiental e na sustentabilidade. Para reduzir este impacto ambiental aumentou o interesse no uso de elicitores incluindo o ácido Jasmônico (AJ) para induzir resistência contra os patógenos e insetos na cultura da pimenteira (Capsicum annum L.), a qual é uma importante hortaliça ou planta olerícola ao redor do mundo. Neste estudo foi comparada a eficácia do ácido Jasmônico no crescimento, resposta fisiológica, produção e controle de viroses na pimenteira. Foi avaliada uma simples aplicação (AJ1), duas aplicações (AJ2), inseticida malathion $50 \%$ e uma testemunha (controle). Os resultados experimentais demonstraram uma redução nos sintomas de doenças viróticas pela atividade das enzimas anti oxidantes (GPX, APX e CAT), que reduziram a porcentagem da incidência e severidade das mesmas e promoveram o crescimento e melhoram os caracteres da produtividade da pimenteira. Portanto, a aplicação do ácido jsmônico em pimenteira pode ser uma alternativa para reduzir o uso de inseticidas e sua aplicação em duas vezes durante o ciclo $(0,5 \mathrm{mM})$ foi mais eficiência.

PALAVRAS-CHAVE: Resistência induzida. Estabilidade oxidativa. Controle alternative de doenças em plantas. Severidade de doença.

\section{REFERENCES}

AEBI, H. Catalase. In: Method of enzymatic analysis 3, ed. Bergmeyer, H. U., pp. 273-277. Verlag Chemie, Weinheim, Germany, 1983 
AROGUNDADE, O.; BALOGUN, O. S.; KAREEM, K. T. Occurrence and distribution of pepper veinal mottle virus and cucumber mosaic virus in pepper in Ibadan, Nigeria. Journal of Virology, v. 9, n.79, p. 1-4, 2012.

AWASTHI, MD.; AHUJA, A. K.; SHARMA, D. Contamination of horticulture ecosystem: Orchard soil and water bodies with pesticide residues. Proc. Nation. Symp. On Integrated Pest Management (IPM) in Horticultural Crops: New Molecules, Biopesticides and Environment, Bangalore, 17-19 October, p. 117, 2001.

BARBOSA, M. A. G.; LARANJEIRA, D.; COELHO, R. S. B. Physiological cost of induced resistance in cotton plants at different nitrogen levels. Summa Phytopathologica, v. 34, n. 4, p. 338-342, 2008. http://dx.doi.org/10.1590/S0100-54052008000400007

BLACK, C. A.; KARBAN, R.; GODFREY, L. D.; GRANETT, J.; CHANEY, W. E. Jasmonic acid: a vaccine against leafminers (Diptera: Agromyzidae) in celery. Environmental Entomology, v. 32, n. 5, p. 1196-1202, 2003. http://dx.doi.org/10.1603/0046-225X(2003)032[1196:JAAVAL]2.0.CO;2

CIPOLLINI, D. F.; REDMAN, A. M. Age-dependent effects of jasmonic acid treatment and wind exposure on foliar oxidase activity and insect resistance in tomato. Journal of Chemical Ecology, v. 25 n. 2, p. 271-281, 1999. http://dx.doi.org/10.1023/A:1020842712349

COOPER, W. R.; RIESKE, L. K. Chestnut species and jasmonic acid treatment influence development and community interactions of gall produced by the Asian chestnut gall wasp, Dryocosmus kuriphilus. Journal of Insect Science, $v .11$, n. 140, p. 1-14, 2011. http://dx.doi.org/10.1673/031.011.14001

CREELMAN, R. A.; TIERNEY, M. L.; MULLET, J. E. Jasmonic acid/methyl jasmonate accumulate in wounded soybean hypocotyls and modulate wound gene expression. Proceedings of the National Academy of Sciences, v. 89, p. 4938-4941, 1992. http://dx.doi.org/10.1073/pnas.89.11.4938

DAVID, B. V. Biotechnological approaches in IPM and their impact on environment. Journal of Biopesticides, v. 1, n. 1, p. 1-5, 2008.

DAVID, P. M. M. Resurgence of yellow mite Polyphagotarsonemus latus on chilli following application of insecticides. Madras Agricultural Journal, v. 78, p. 88-91, 1991.

DOA, Department of Agriculture, $15^{\text {th }}$ September 2012 at www.moa.gov.my.

El-KHALLAL, S. M.; HAMDIA, M. A.; El-BAKI, G. K. A. Induction and modulation of resistance in tomato plants against fusarium wilt disease by bio agent fungi (Arbuscular Mychoryza) and/or hormonal elicitors (jasmonic acid \& salicylic acid): 2-changes in the antioxidant enzymes, phenolic compounds and pathogen related-proteins. Australian Journal of Basic and Applied Science, v. 1, n. 4, p. 717-732, 2007.

GALANIHE, L. D.; PRIYANTHA, M. G. D. L.; YAPA, D. R.; BANDARA, H. M. S. RANASINGHE, J. A. D. A. R. Insect pest and disease incidences of exotic hybrids chilli pepper varieties grown in the low country dry zone of Sri Lanka. Annals of Sri Lanka v. 6, p. 99-106, 2004.

HOWE, G. A.; JANDER, G. Plant immunity to insect herbivores. Annual Review of Plant Biology, v. 59, p. 41-66, 2008. http://dx.doi.org/10.1146/annurev.arplant.59.032607.092825

Il'inskaya, L. I; Chalenko, G. I.; Perekhod, E. A.; Gerasimova, N. G.; Ozeretskovskaya, O. L. Effect of methyl jasmonate on arachidonic acid-induced resistance of potato to late blight, Applied Biochemistry and Microbiology. v. 36, n. 2, p. 181-186, 2000. http://dx.doi.org/10.1007/BF02737917 
JAYARAJ, J.; MUTHUKRISHNAN, S.; LIANG, G. H.; VELAZHAHAN, R. Jasmonic acid and salicylic acid induce accumulation of b-1, 3-glucanase and thaumatin-like proteins in wheat and enhance resistance against Stagonspora nodorum. Biologia Plantarum, v. 48, p. 425-430, 2004.

http://dx.doi.org/10.1023/B:BIOP.0000041097.03177.2d

LORENZO, O.; SOLANO, R. Molecular players regulating the jasmonate signaling network. Current Opinion in Plant Biology, v. 8, p. 532-540, 2005. http://dx.doi.org/10.1016/j.pbi.2005.07.003

NAKANO, Y.; ASADA, K. Hydrogen peroxide is scavenged by ascorbate-specific peroxidase in spinach chloroplasts. Plant and Cell Physiology, v. 22, n. 5, p. 867-880, 1981.

OUZOUNIDOU, G.; ILIAS, I.; GIANNAKOULA, A.; PAPADOPOLOU, P. Comparative study on the effects of various plant growth regulators on growth, quality and physiology of Capsicum annuum L. Pakistan Journal of Botany, v. 42, n. 2, p.: 805-814, 2010.

RAO, M. V.; PALIYATH, G.; ORMROD, D. P.; MURR, D. P.; WATKINS, C. B. Influence of salicylic acid on $\mathrm{H}_{2} \mathrm{O}_{2}$ production, oxidative stress, and $\mathrm{H}_{2} \mathrm{O}_{2}$-metabolizing enzymes. Plant Physiology, v. 115, p. 137-149, 1996. http://dx.doi.org/10.1104/pp.115.1.137

SAS User's Guide. Statistics. SAS Inst, Cary, NC, 2009).

SHIH, S. L.; TSAI, W. S.; GREEN, S. K.; SINGH, D. First report of Tomato leaf curl Joydebpur virus infecting chilli in India. Plant Pathology, v. 56, n. 2, p. 341, 2007. http://dx.doi.org/10.1111/j.13653059.2007.01540.x

THALER, J. S. Induced resistance in agricultural crops: Effects of jasmonic acid on herbivory and yield in tomato plants. Environmental Entomology, v. 28, n. 1, p. 30-37, 1999. http://dx.doi.org/10.1093/ee/28.1.30

THALER, J. S.; STOUT, M. J.; KARBAN, R.; DUFFEY, S. S. Exogenous jasmonates simulate insect wounding in tomato plants (Lycopersicon esculentum) in the laboratory and field. Journal of Chemical Ecology, v. 22, p. 1767-1781, 1996. http://dx.doi.org/10.1007/BF02028503

TIWARI, T. P.; BHARTI, S. K.; KAUR, H. D.; DIKSHIT, R. P.; HOONDAL, G. S. Synergistic antimicrobial activity of tea and antibiotics. Indian Journal of Medical Research, v. 122, n. 1, p. 80-84, 2005.

VON DAHL, C. C.; BALDWIN, I. T. Methyl jasmonate and cis-jasmone do not dispose of the herbivoreinduced jasmonate burst in Nicotiana attenuata. Physiologia Plantarum, v. 120, p. 474-481, 2004. http://dx.doi.org/10.1111/j.0031-9317.2004.00269.x

WASTERNACK, C. Jasmonates: an update on biosynthesis, signal transduction and action in plant stress response, growth and development. Annals of Botany, v. 100, p. 681- 697, 2007.

http://dx.doi.org/10.1093/aob/mcm079 